\title{
The Effect of Improvisation Technique towards EFL Students' Speaking Ability
}

Received:14 ${ }^{\text {th }}$ April 2017; Revised: $21^{\text {st }}$ April 2017; Accepted: $15^{\text {th }}$ July 2017

Permalink/DOI: http://dx.doi.org/10.15548/jt.v24i2.290

\section{Hadeli *)}

Universitas Islam Negeri Imam Bonjol

Padang, Indonesia.

E-mail: ha_deli@yahoo.com

\section{Eviarni}

Universitas Islam Negeri Imam bonjol

Padang, Indonesia.

E-mail: eviarni@gmail.com

\begin{abstract}
The purpose of this research was to determine whether Improvisation Technique gave significant difference in teaching transactional and interpersonal conversation text toward students' speaking ability. This research was also aimed to find out which components of students' speaking were mostly improved after using Improvisation Technique. True experimental research was used where the sample was chosen by using cluster random sampling. The result of this research showed that the students had made some progresses. It showed that the mean score of students' speaking ability in experimental class (79.50) was higher than the mean score of students' speaking ability in control class (72.21). It means that teaching speaking by using Improvisation Technique gives significant effect towards students' speaking ability. Based on the research finding, it can be concluded that using Improvisation Technique gave significant effect towards students' speaking ability at class XI of Senior High School 12 Padang. Thus, it is recommended for English teacher should consider the use of Improvisation Technique as an alternative technique in teaching speaking for getting significant effect towards students' speaking ability.
\end{abstract}

Keywords: Improvisation technique, speaking ability, EFL students

How to Cite: Hadeli, H., \& Eviani, E. (2017). The effect of improvisation technique towards EFL students' speaking ability. Al-Ta Lim Journal, 224 (2). doi:http://dx.doi.org/10.15548/jt.v24i2.290

\section{INTRODUCTION}

Education policy for English language teaching in Indonesia has undergone several changing. The changing aims at improving the outcomes of English language teaching itself. In 2004, the ministry of National Education has decided to bring in a new curriculum in all subjects areas, including English. The curriculum was known as Competence Based Curriculum or 2004 curriculum which recommended a new approach that is Genre Based Approach.
According to Competence Based Curriculum for Senior High School, English is a tool to communicate in spoken and written form. And the language has a central role in development of intellectual, social, and students' emotional and is a key to succeed in studying all fields. Based on curriculum 2006, the purpose of teaching English is to develop students' communication ability of its language in oral and written (Belcher, 2006; Echevarria, Short, \& Powers, 2006; Hinkel, 2006; Hyland \& Hyland, 2006; Kim, 2006; Kramsch, 2006; Nunan, 2006). The ability consists of four skills (listening, speaking, 
reading and writing). To achieve that purpose in teaching English, Competence Based Curriculum suggested Genre Based Approach. The Genre approach is concerned with providing students with explicit knowledge about language. It values teacherlearner interaction as well as interaction between students. The cycle of teaching and learning activities in the genre based approach consists of four stages, they are: (1) Building knowledge of the field; (2) Modeling of the text; (3) Joint construction of the text; and (4) Independent construction of the text (Derewianka, 2003; Hyland, 2007, 2008; Richards \& Rodgers, 2014).

Today, English has become a world language that is used in business, education, world news, and international communication. However, in Indonesia, English as a Foreign Language, it was somehow very difficult for students to communicate with other people in English effectively. Although speaking was not being tested in National Examination (UN), it was used in interaction that involves the way of acquiring the language, producing, and understanding the information.

Based on the English standard competence of curriculum 2006, the essential part in speaking especially for Senior High School is being able to express the meaning of transactional and interpersonal conversation text formally and sustained in the context of everyday life. The goals of teaching speaking in classroom for students are to respond and and to use the speech of various expressions. Based on the preliminary study, it was found that there were many difficulties that impede the students' speaking skills. They were because: (1) lack of vocabulary; (2) unfeeling confident to pronounce the English word; (3) feeling anxiety and afraid of making mistakes; (4) students' motivation in speaking English, (5) students' initiative to practice and exercise during speaking lesson.

In this study the researcher used improvisation technique. Some benefits might be gained from the implementation of improvisation technique. Green, 2012 also proved that improvisations technique does help communication skill, especially interpersonal skill. Improvisations technique is a good way to improve students' confidence to speak English. There was 25\% of average score improvement in speaking (Fauzan, 2014; Kennedy, 2005; Oreck, 2004; Shehadeh, 2011; Usman, 2015).

In this study the researcher used improvisation technique. Some benefits might be gained from the implementation of improvisation technique. Green (2012) also proved that improvisations technique does help communication skill, especially interpersonal skill.

Based on the benefits of improvisations technique, the researcher was interested in implementing this technique at class XI with some adjustments. Because of improvisation technique was not being applied yet by the English teacher of Senior High School 12 Padang. And also improvisations technique would decrease their reliance on Minang Language and allowed them to utilize the vocabulary and grammatical structures of English more naturally. Richards \& Rodgers, 2014 says 'the best practice in any situation will depend on the type of student, the words that are targeted, the school system and curriculum, and many other factors'. With improvisation technique, the students had many times to practice while learning. The main question of this research is: Is there significant difference of the students' achievement in speaking ability by using improvisation technique? To answer these questions, so conducting the research was needed under the title: "The Effect of Improvisation Technique towards Students' Speaking Ability at Class XI of Senior High School 12 Padang"

This research was significant to conduct based on benefits: (1) Teacher is more creative in choosing the strategies and techniques in teaching process; (2) Teacher can demonstrate the usefulness of exercises once or twice in the beginning to build rapport and trust with the students, and (3) 
Students of all levels are able to practice the language immediately in learning the material.

Boesen, Herrier, Apgar, \& Jackowski (2009) indicated that pharmacy students felt that the improvisation sessions had a positive impact on their overall communication skills. Using improvisation training to improve pharmacy students' communication skills should be considered and could be readily implemented in other colleges. Whereas in this research was using improvisation activities to improve speaking ability. Fauzan (2014), (2016); Umar, (2016) Improvisations technique is a good way to improve students' confidence to speak English. There was 25\% of average score improvement in speaking. He conducted his action research to the University students. While in this research was conducted to the Senior High School students.

Green (2012) Improvisation is very useful in innovation. Adebiyi \& Adelabu (2013) concluded that improvisation encourages adaptability, fluency, and communicative competence and encourages students to mobilize their vocabulary, respond to grammatical and syntactical accuracy, and develop cultural and social awareness, and gain confidence and fluency. He used the improvised drama, games and songs and conducted it to the University Students.

Fisk, Grove, Daly, \& Ganz (2007) found that improvisation training has practical and positive outcomes for frontline service workers in a people-processing service context. They wrote based on a case study while in this research was experimental research. Hackbert (2010) concluded with improvisation exercises they greatly increase the trust, familiarity, enthusiasm and social skills that are needed to overcome inhibitions that often stand in the creative process.

\section{METHOD}

Population on this research was students at class XI of Senior High School 12 Padang in academic year 2016-2017. The class XI students were grouped into five classes (XI IPA.1, XI IPA.2, XI IPA.3, XI IPA.4, and XI IPS.1). Each class consists of about 32 students. It means that the total population was about 159 students. They chose as the population based on the assumption that they have a basic knowledge in speaking. They were also taught with the same material and syllabus. The five classes had different characteristic such as motivation in learning, discipline, classroom management and so on. The population of this research was: After deciding the population, the researcher used SPSS 16.0 to show normality and homogeneity from the five classes above. To get representative sample for this research, the researcher had done these steps:

a. Collect the midterm test scores the entire students grade XI from the teacher.

b. Test of normality. For this research, the normality test analyzed with using SPSS 16.0 (statistical product and service solution) and used Kolmogorov Smirnov and Shapiro Wilk. The data was normal if every class has significance score bigger than 0.05 .

Researcher listed all clusters and determined the number of clusters. Then, researcher used piece of paper and wrote the number for each piece of paper (XI IPA.1, XI IPA.2, XI IPA.3, XI IPA.4, and XI IPS.1). Then researcher randomly selected the needed number of clusters. The clusters which were chosen were XI IPA.1, and XI IPA.2 as sample.

The researcher had selected two classes were normal and homogeny as the sample after using SPSS 16.0. By following the steps in clustering sampling, researcher found XI IPA.1 and XI IPA.2. Beside that the students in both of class had same level of English knowledge since they are taught by the same material and teacher. In determining which experimental class was, it was chosen by following the procedure of flipping coin to divide class into experiment and control. The result of flipping coin, researcher obtained 
class XI IPA.1 as experimental class and class XI IPA.2 as control class.

Table 1. Sample of the Research

\begin{tabular}{ccc}
\hline No & Class & $\begin{array}{c}\text { Number of } \\
\text { students }\end{array}$ \\
\hline 1 & $\begin{array}{c}\text { XI IPA 1 (Experimental } \\
\text { Class) }\end{array}$ & 32 \\
2 & XI IPA 2 (Control Class) & 32 \\
\hline
\end{tabular}

The researcher had done the teaching at Senior High School 12 Padang. The location was chosen for the reason that the researcher had ever done the observation there, there also had never been any research concerning the involving technique of this research and that school was one of the nearest schools from the researcher's permanent address. The researcher has done the research in school on October to November 2016 in academic year $2016 / 2017$ at first semester. This research was conducted on six meetings in several weeks. The meeting was done every Wednesday and Saturday in Experimental Class, and Wednesday and Thursday in Control Class. The teaching process was twice a week for both experimental and control classes.

According Sugiyono (2013) research variable is an attribute or nature or assess from people, object or activity having certain variation of specified by researcher to be learned and then took its conclusion. There were two variables in this research:

a. Independent variable

Independent variable is variable which was influencing or affecting an outcome or dependent variable. Independent variable in this research was teaching and learning process by using improvisation technique. Improvisation technique is a technique where students are given roles or perform dialogue or conversation using their own word or sentences based on the conversation situation on clue given. Improvisation was as a treatment in teaching and learning process.

b. Dependent variable

Dependent variable is variable which was influenced or becoming effect caused by independent variable. Dependent variable in this research was students' achievement of speaking ability at class XI Senior High School 12 Padang.

Students achievement is ability owned by the students in both experimental and control class after they accepted the learning experiences. Student's achievement in this research was students' score from speaking test.

This research used test as instrument. The test was oral test. This test would know the students' speaking abilities in speaking for example: pronunciation, grammar, fluency, vocabulary and comprehension. The test had been made by the researcher based on the curriculum and syllabus in that school. The researcher asked the students in groups to prepare the chosen topic into transactional conversation and performed in front of the teacher. The researcher gave some pictures about person, animal and so on to ease them in making good conversation. Then the researcher scored the test. In scoring the test, researcher used the Hughes categories.

Before doing the post test, the researcher shared or discussed about speaking test with supervisors and English teacher at the school in order to know the test is validity and reliability. The data of this research was collected by giving speaking test. The data of this research was student's score in process and test. Treatment is the process of using improvisation technique in teaching and learning process to improve the student's speaking ability.

While test was the process of evaluating the understanding after giving the treatment, it aimed to conclude the contribution of improvisation technique in teaching and learning speaking process to students' speaking ability. In this research, there was no giving pre-test because the researcher analyzed the students' mean score of speaking post-test in both experimental and control classes. 
Moreover, speaking test used to know the students' pronunciations, vocabulary, grammar, fluency and comprehension with improvisation technique. The data was described quantitatively. After preparing and organizing the data, the researcher analyzed it. Analyzing the data was to address each one of your research questions or hypothesis. It was to see the different progress of the student's speaking those taught with improvisation technique and conventional technique. Questions or hypothesis in quantitative research require.

Descriptive analysis or descriptive statistics that indicated general tendency in the data (mean) and the spread of scores (variance, standard deviation, and range). Inferential data analysis or inferential statistics was needed to compare two classes on the independent variable in terms of the dependent variable. The researcher also did normality and homogeneity to analyze the data before using t-test.

\section{RESULT AND DISCUSSION}

In this subtitle presented the description of data that students had taken the test of each class. The data of this research are the score of students' test between experimental and control classes. Before doing the test, the researcher applied improvisation technique for experimental class and without technique for control class for several meetings. Then the last meeting, test was given to the students. The test between the two classes was similar where the students chose one topic and then speak concerning how they express their idea about something. The students' speaking test result was evaluated by considering five components; accent (pronunciation), grammar, vocabulary, fluency, and comprehension.

All the data were analyzed to find out the Range, Mean score ( $\overline{\mathrm{X}})$, Maximum score, Minimum score, Variance and Standard Deviation (SD) of test in both experimental and control classes. Based on data which was gathered from 64 students specified by as sample, data of students' achievement on speaking ability will be tabulated as follow. Before going to the tabulating, we had to find those intervals.

\begin{tabular}{cccc}
\hline$H$ & $n=32$ & $R=H-L$ & $\begin{array}{l}\text { Percentage } \\
=\text { F } \times 100 \\
8\end{array}$ \\
9 & & & $\mathrm{n}$ \\
$L$ & i.e. $=$ & $K=1+3.3 \log n$ & \\
$=$ & $R / K$ & & \\
6 & & & \\
0 & & & \\
\hline
\end{tabular}

$$
\begin{aligned}
R & =H-L \\
& =89-60=29 \\
K & =1+3.3 \log n=1+3.3 \log 32 \\
& =1+3.3(1.50) \\
& =1+4.95=5.95=6 \\
i & =\frac{R}{K}=\frac{29}{6}=4.83=5
\end{aligned}
$$

Then, the students' score of test in experimental class can be seen in the table below: From the table above, students' speaking score of posttest in experimental class is ranging from $85-89$, there were 7 $(21.87 \%)$ students. There were 12 (37.5\%) students who got in the interval of 80-84. In the interval 75-79, there were $6(18.75 \%)$ students. Next, there were $5(15.62 \%)$

\begin{tabular}{|c|c|c|c|}
\hline $\begin{array}{r}H= \\
85\end{array}$ & $n=32$ & $R=H-L$ & $\begin{array}{l}\text { Percentage } \\
=\underline{F} \times 100\end{array}$ \\
\hline $\begin{array}{r}L= \\
59\end{array}$ & $\begin{array}{l}\text { i.e. }= \\
R / K\end{array}$ & $K=1+3.3 \log n$ & $\mathrm{n}$ \\
\hline
\end{tabular}
students who got score at the interval 70-74. There was $1(3.12 \%)$ student who got score at the interval 65-69. The last, at the interval 6064 , there was $1(3.12 \%)$ student.

\section{Control}

$$
\begin{aligned}
R & =H-L \\
& =85-59=26 \\
K & =1+3.3 \log n=1+3.3 \log 32=5.95=6 \\
i & =\frac{R}{K}=\frac{26}{6}=4.33=4
\end{aligned}
$$


Then, the students' score of test in control class can be seen in the table below:

Table 2. The Data of Test Students' Speaking Score in Control Class

\begin{tabular}{ccc}
\hline Interval & Frequency & Percentage \\
\hline $83-86$ & 1 & $3.12 \%$ \\
$79-82$ & 6 & $18,75 \%$ \\
$75-78$ & 4 & $12,5 \%$ \\
$71-74$ & 10 & $31,25 \%$ \\
$67-70$ & 3 & $9,37 \%$ \\
$63-66$ & 5 & $15,62 \%$ \\
$59-62$ & 3 & $9,37 \%$ \\
& $\mathrm{n}=\mathbf{3 2}$ & $\mathbf{1 0 0 \%}$ \\
\hline
\end{tabular}

Besides that, it shows that most of students' speaking score of post-test in control class is ranging from $83-86$, there was $1(3.12 \%)$ student who got in that interval. Next, there were $6(18.75 \%)$ students who got ranging from $79-82$. While the interval $75-78$ there were $4(12.5 \%)$ students who got the score at that interval. And the interval 71-74 there were $10(31.25 \%)$ students who got the score at that interval. Then there were 3 $(9.37 \%)$ students who got score at the interval $67-70$ and ranging from $63-66$, there were 5
(15.62\%) students. Furthermore, 59-62, there were $3(9.37 \%)$ students who got score around that interval.

\section{Mean scores}

After tabulating, we looked for the mean scores in both experimental and control classes. This following was calculation process to find out the means of the data: After conducting treatment for the experimental class, the test was administered for both experimental and control to find out speaking score progress of the two classes. Meanwhile, the students' mean score of experimental and control classes can be seen in the following From the table above, it can be seen that the means from both experimental and control classes posttest were rather different. However, to prove that the means of both classes were significantly different, several tests were calculated. The next explanation was the result of several tests on posttest scores.

\section{Standard deviation}

This following was calculation process to find out the standard deviation of the data:

Table 3. Calculation Process of Standard Deviation of Experimental Class

\begin{tabular}{ccccccc}
\hline Interval & $\mathrm{F}_{1}$ & $\mathrm{X}_{1}$ & $\mathrm{~F}_{1} \mathrm{X}_{1}$ & $X_{1}-\overline{\mathrm{X}_{1}}$ & $\left(X_{1}-\overline{\mathrm{X}_{1}}\right)^{2}$ & $\mathrm{~F}_{1}\left(X_{1}-\overline{\mathrm{X}_{1}}\right)^{2}$ \\
\hline $85-89$ & 7 & 87 & 609 & 7.5 & 56.25 & 393.75 \\
$80-84$ & 12 & 82 & 984 & 2.5 & 6.25 & 75 \\
$75-79$ & 6 & 77 & 462 & -2.5 & 6.25 & 37.5 \\
$70-74$ & 5 & 72 & 360 & -7.5 & 56.25 & 281.25 \\
$65-69$ & 1 & 67 & 67 & -12.5 & 156.25 & 156.25 \\
$60-64$ & 1 & 62 & 62 & -17.5 & 306.25 & 306.25 \\
& $\mathbf{\Sigma} \mathrm{F}_{1}=\mathbf{3 2}$ & & $\mathbf{\Sigma} \mathrm{F}_{1} \mathrm{X}_{1}=\mathbf{2 5 4 4}$ & & & $\mathbf{\Sigma} \mathrm{F}_{1}\left(X_{1}-\overline{\mathrm{X}_{1}}\right)^{2}=\mathbf{1 2 5 0}$ \\
\hline
\end{tabular}

$\mathrm{S}_{1}^{2}=\frac{\sum \mathrm{F}_{1}\left(X_{1}-\bar{X}_{1}\right)^{2}}{\sum \mathrm{F}_{1}}$

$\mathrm{S}_{1}^{2}=\frac{1250}{32}=39.0625$

$S_{1}=\sqrt{39.0625}=6.25$ 
Table 4. Standard Deviation of Test

\begin{tabular}{lcccc}
\hline \multicolumn{1}{c}{ Class } & $\begin{array}{c}\text { Maximum } \\
\text { Score }\end{array}$ & $\begin{array}{c}\text { Minimum } \\
\text { Score }\end{array}$ & Variance & $\begin{array}{c}\text { Standard } \\
\text { Deviation }\end{array}$ \\
\hline Experimental & 89 & 60 & 39.06 & 6.25 \\
Control & 85 & 59 & 43.36 & 6.58 \\
\hline
\end{tabular}

From the table above, the highest score after giving treatment in experimental class is 89, whereas the highest score in control class is 85. The lowest score of post-test in experimental class is 60 and the lowest one is 59. While variance in experimental class is 39.06 and control class is 43.36. Standard deviation in experimental class is 6.25 and standard deviation in control class is 6.58 . The mean score of every speaking component of the two classes is somewhat different. And will be clear in next explanation.

\section{Charts}

In order to see clearly about the data, the researcher presented the charts as follows:

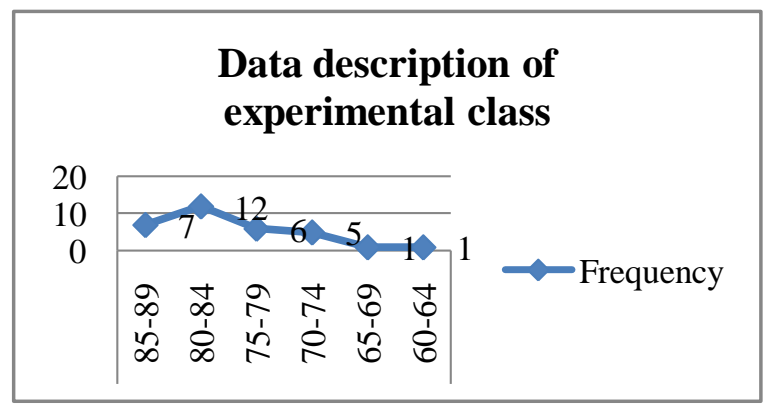

Figure 1: Data Description of Experimental Class

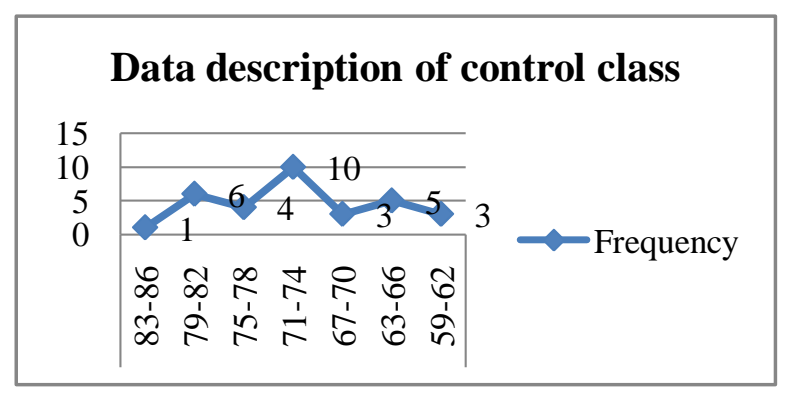

Figure 2. Data Description of Control Class

\section{The normality of distribution test}

To check whether the test scores of experimental class and controll class were normal, the Kolmogorov-Smirnov (K-S) test was performed in SPSS 16.0. The result of K$\mathrm{S}$ test indicated that the data were normally distributed. Moreover, significance score of the experimental class $\left(\mathrm{XI} \mathrm{IPA}_{1}\right)$ was $D(32)=$ $0.100, p>0.05$ and the control class (XI $\mathrm{IPA}_{2}$ ) was $D(32)=0.200, p>0.05$.

Table 5. The Result of Normality Distribution

\begin{tabular}{|c|c|c|c|c|c|c|c|}
\hline \multicolumn{8}{|c|}{ Tests of Normality } \\
\hline \multirow{4}{*}{ VAR00001 } & & \multicolumn{3}{|c|}{ Kolmogorov-Smirnov $^{\mathrm{a}}$} & \multicolumn{3}{|c|}{ Shapiro-Wilk } \\
\hline & VAR00002 & Statistic & Df & Sig. & Statistic & df & Sig. \\
\hline & $\begin{array}{c}\text { XI IPA } 1 \\
\text { (Experimental } \\
\text { Class) }\end{array}$ & .142 & 32 & .100 & .942 & 32 & .088 \\
\hline & $\begin{array}{c}\text { XI IPA } 2 \text { (Control } \\
\text { Class) }\end{array}$ & .109 & 32 & $.200^{*}$ & .957 & 32 & .233 \\
\hline & st distribution is no & & & & & & \\
\hline
\end{tabular}

It was revealed that the distribution was normal. The number in bracket is the degrees of freedom $(d f)$ from the table. The table of the normal distribution test result can be seen clearly at the appendix. If the data around and near with the curve line, it means the data was normal. 
To check the homogeneity of variance of the data, Levene's test was conducted. The result of calculating using Levine test is as follows:

Table 6. The Result of Variances Homogeneity Test on Posttest

\begin{tabular}{cccccc}
\hline \multicolumn{5}{c}{ Test of Homogeneity of Variance } \\
\hline & Levene & & & \\
VAR00001 & Statistic & df1 & df2 & Sig. \\
& Based on Mean & .246 & 1 & 62 & .622 \\
& Based on Median & .389 & 1 & 62 & .535 \\
& Based on Median and with & .389 & 1 & 61.850 & .535 \\
& adjusted df & & & & \\
& Based on trimmed mean & .304 & 1 & 62 & .584 \\
\hline
\end{tabular}

The table shows that the significance value (based on mean) is 0.246 . It means that the probability is higher than $0.05(p>0.05)$. Therefore, the result of the test indicated that the students' test scores in both classes were equal. The table of the homogeneity of variance test result can be seen clearly at the appendix.

As the result of analyzing the data, it was found that t-observed of test was 4.730, while the value of the t-table is 1.671 at the degree of freedom are 62 and significant score is 0.05 . In conclusion, the value of t-observed in this research was higher than the value of $t-$ table. It means that there is significant differences of the students' achievement between those taught with improvisation technique and those taught with conventional one in class samples of Senior High School 12 Padang. Or we can say that students' achievement those taught with improvisation technique was higher than those taught with conventional technique. So the hypothesis was accepted.

Improvisation is one of techniques in speaking that give significant influence to improve students' speaking ability. As Crossan, Cunha, Vera, \& Cunha (2005) says that improvisation as "intuition guiding action in a spontaneous way". The researcher also found the students' degrees of intuition and spontaneity of action. Crossan et al. (2005) define improvisation as the spontaneous and creative process of attempting to achieve an objective in a new way. And the researcher had been guiding the students to develop their intuition and creativeness in order to speak spontaneously while teaching activity.

Related to the purpose of this research is to determine whether there is significant difference of the students' achievement in speaking ability between those taught with improvisation technique and those taught with conventional technique at class XI of Senior High School 12 Padang.

The researcher can say that there is significant difference of the students' achievement between those taught with improvisation technique and those taught without improvisation technique.

In previous findings explanation, it was the test result analysis for both classes. The hypothesis testing proved that the use of improvisation technique in teaching and learning process of speaking gave significant improvement towards students' speaking ability in class XI of Senior High School 12 Padang. It showed from the mean score of experimental class was bigger than control class. The comparison of two mean scores was 79.50 (experimental): 72.12 (control). It means that the learning outcome of teaching speaking with improvisation technique is higher than the learning outcome of teaching speaking with conventional technique.

Based on the students' score in speaking test, students' experimental class score after giving five treatments was experiencing of 
progress for all speaking components itself, there were pronunciation, grammar, vocabulary, fluency and comprehension. The highest improvement vocabulary, the difference of score in both experimental and control classes was 2.56. Furthermore, students' comprehension had become second of highest score that was had difference 1.62 for both classes, as similar as fluency had 1.62 for both classes. Grammar had difference 1.00. The lowest difference was pronunciation that was had difference 0.15 for both classes.

\section{Vocabulary}

Richard defines vocabulary is a set of lexemes, including single words, compound words and idioms. One cannot communicate effectively or express their ideas both oral and written form if they do not have sufficient vocabulary. It indicates that the richness of vocabulary will extremely affect one's ability to speak a language. After using Improvisation Technique, the students got improvement in vocabulary. It is proven from the result; its difference was 2.56 point between experimental (22.12) and control (19.56) classes. Because students practice the language immediately on learning the material, the students have produced much vocabulary in expressing their ideas about something. As Koppett (2001) says all students get to express them creatively, to play together.

\section{Comprehension}

Comprehension can be defined as understanding what is being heared and producing in right meaning (Scovel, 2001: 50). After using Improvisation Technique, the students got significant improvement in comprehension. It is proven from the result; its difference is 1.62 point between experimental (17.00) and control class (16.28). Because Spolin (1999) says that the goal of improvisation is to "solve a problem." Improvisation technique makes students to enhance creative thinking and action in expressing their ideas about something. In addition, Lemon, 2005 also states improvisation advance effectiveness in enhancing creative, innovation thinking and personal growth for individuals at all ability levels.

\section{Fluency}

Fluency is the features which give speech the qualities of being natural and normal, including native-like use of pausing, rhythm, intonation, stress, rate of speaking, and use of interjections and interruptions (Mayer, 2002; Wenger, McDermott, \& Snyder, 2002). After using Improvisation Technique, the students got improvement in fluency. Mayer (2002) says through the practice of improvisation, the students also foster a climate conducive to participation and growth. Most of students had participated more in speaking and their ability in in expressing their ideas about something had significantly improved. Its difference was significant 1.62 point between experimental (10.62) and control (9.00) classes.

\section{Grammar}

The grammar of a language is the structures of a language and the way in which linguistic units such as words and phrases are combined to produce sentences in the language (Richards \& Rodgers, 2014). Lee states by using improvisation technique, the students themselves engage in using the language rather than thinking about the form of the language. Students still arrange incorrect sentence in conversation of expressing asking and giving opinion. In short, while speaking, students still difficult to construct the rule of word inductively in order to give meaning for all the words. The students still had difficult in practicing grammar or in constructing sentences with good pattern. It is proven from the result, after using Improvisation Technique the students got little of improvement in grammar. Its difference was 1.00 point between experimental (26.12) and control (25.12) classes.

\section{Pronunciation}


Pronunciation is the way a certain sounds are produced (Richards, 2015). It is students' way to produce clearer language when they speak. It deals with the phonological process that refers to the component of a grammar made up of the elements and principles that determine how sounds vary and pattern in a language. After using Improvisation Technique, the students got improvement in pronunciation. But the improvement was not significant. The students still have difficult in pronouncing the word. Its difference was only 0.15 point between experimental (2.40) and control (2.25) classes.

Based on the data, the score of all components of the experimental class was higher than control class. It was clear that there was significant difference of students' achievement those taught with improvisation technique in speaking ability, especially for vocabulary, comprehension, fluency and also for the other components that were grammar, and pronunciation.

The value of $t$-calculated score of (4.730) was bigger that the value of t-table $(1.671)$ at the degree of freedom $(32+32-2)=$ 62 , and the level of significance was 0.05 , so the hypothesis was accepted.

Based on the explanation above, the hypothesis that the students' achievement of speaking ability those taught with improvisation technique was higher than those taught with conventional technique was statistically accepted.

Overall, most of students had been expressed themselves creatively, played together, had their ideas honored, and had their mistakes forgiven. Improvisation technique gave significant difference towards students' speaking ability and self confidence in speaking.

When improvisation is used in teaching, students provided different responses throughout the class session, and the instructor did not evaluate any given response but instead facilitated the improvisation process among the students, with the goal of guiding them toward discovery of their own knowledge (Sawyer, 2004).

\section{CONCLUSION AND RECOMENDATION}

Based on the data analyzed in the previous chapter, it can be concluded that after the treatment, the experimental class's test score was better than control class's score. There were significant differences between the students' speaking ability in expressing asking and giving opinion of the experimental class which received improvisation technique and the students' speaking ability of the control class which received conventional technique. The statistical computation showed that in the test, the mean score of experimental class was 79.50 while in control class was 72.12 . This computation reflected that the mean of experimental class's score was higher than the mean of the control class's score. It was indicated that improvisation technique affecting students' speaking achievement was better than normal.

It was proved by the students' speaking improvement which was shown in some main indicators of speaking; pronunciation, grammar, vocabulary, fluency and comprehension. The students in experimental class gained more improvement in their pronunciation, grammar, vocabulary, fluency and comprehension. After the treatment was given, the experimental class's students were found that they pronounce English words more accurately, speak English -how they express their idea about something- more fluently and with more accurate grammar, use more vocabulary, and understand what their friends and teacher said in English more easily. The $\mathrm{t}_{\text {observed }}$ of independent sample $\mathrm{t}$ test, which higher than $t_{\text {table }}(4.730>1.671)$, shows that the test score of the experimental and control class is significantly different.

To sum up, improvisation technique is a good way to improve students' vocabulary to speak English especially in expressing of asking and giving opinion. By having more 
vocabulary and self-confidence, they were able to talk much in English. Talking much in English had big contribution to build their fluency. Then, their fluency was a high way to improve their speaking ability.

Finally, conducting this research at Senior High School 12 Padang had several advantages for researcher or educational institution, the teacher and the students so. The important thing is improvisation technique can improve students' speaking ability.

\section{REFERENCES}

Adebiyi, A., \& Adelabu, B. (2013). Improvisation as a tool for developing students' competence in English language: a study of the Federal University Of Agriculture, Abeokuta, Nigeria. International Journal of Education and Research, 1(11).

Belcher, D. D. (2006). English for specific purposes: Teaching to perceived needs and imagined futures in worlds of work, study, and everyday life. TESOL Quarterly, 40(1), 133-156.

Boesen, K. P., Herrier, R. N., Apgar, D. A., \& Jackowski, R. M. (2009). Improvisational exercises to improve pharmacy students' professional communication skills. American Journal of Pharmaceutical Education, 73(2), 35 .

Crossan, M., Cunha, M. P. E., Vera, D., \& Cunha, J. (2005). Time and organizational improvisation. Academy of Management Review, 30(1), 129-145.

Derewianka, B. (2003). Trends and issues in genre-based approaches. RELC Journal, 34(2), 133-154.

Echevarria, J., Short, D., \& Powers, K. (2006). School reform and standardsbased education: A model for Englishlanguage learners. The Journal of
Educational Research, 99(4), 195211.

Fauzan, U. (2014). The Use of Improvisations Technique to Improve the Speaking Ability of EFL Students. Dinamika Ilmu: Jurnal Pendidikan, 14(2), 264287.

---. (2016). Enhancing speaking ability of EFL Students through debate and peer assessment. EFL Journal: Journal of EFL, Linguistics, and Literature, 1(1), 49-57.

Fisk, R. P., Grove, S. J., Daly, A., \& Ganz, W. (2007). Service arts: Broadening the services field. In presentation at the AMA Frontiers in Service Conference, San Francisco, California.

Green, B. (2012). Impact of improvisation on interpersonal communication. Gonzaga University.

Hackbert, P. H. (2010). Using improvisational exercises in general education to advance creativity, inventiveness and innovation. Online Submission, 7(10), $10-21$.

Hinkel, E. (2006). Current perspectives on teaching the four skills. TESOL Quarterly, 40(1), 109-131.

Hyland, K. (2007). Genre pedagogy: Language, literacy and L2 writing instruction. Journal of Second Language Writing, 16(3), 148-164.

Hyland, K. (2008). Genre and academic writing in the disciplines. Language Teaching, 41(4), 543-562.

Hyland, K., \& Hyland, F. (2006). Feedback on second language students' writing. Language Teaching, 39(2), 83-101.

Kennedy, A. (2005). Models of continuing professional development: a framework for analysis. Journal of InService Education, 31(2), 235-250. 
Kim, S. (2006). Academic oral communication needs of East Asian international graduate students in nonscience and non-engineering fields. English for Specific Purposes, 25(4), 479-489.

Koppett, K. (2001). Training to imagine. Sterling: Stylus Pubilcations.

Kramsch, C. (2006). From communicative competence to symbolic competence. The Modern Language Journal, 90(2), 249-252.

Mayer, R. E. (2002). Multimedia learning. Psychology of Learning and Motivation, 41, 85-139.

Nunan, D. (2006). Task-based language teaching. Ernst Klett Sprachen.

Oreck, B. (2004). The artistic and professional development of teachers: A study of teachers' attitudes toward and use of the arts in teaching. Journal of Teacher Education, 55(1), 55-69.

Richards, J. C. (2015). Key Issues in Language Teaching. Cambridge University Press.

Richards, J. C., \& Rodgers, T. S. (2014). Approaches and methods in language teaching. Cambridge university press.
Sawyer, R. K. (2004). Creative teaching: Collaborative discussion as disciplined improvisation.

Educational Researcher, 33(2), 12-20.

Shehadeh, A. (2011). Effects and student perceptions of collaborative writing in L2. Journal of Second Language Writing, 20(4), 286-305.

Spolin, V. (1999). Improvisation for the theater: A handbook of teaching and directing techniques. Northwestern University Press.

Sugiyono, P. D. (2013). Metode Penelitian Manajemen. Bandung: Alfabeta, $C V$.

Umar, F. (2016). Developing EFL speaking materials for the second semester Students of STAIN Samarinda.

Usman, A. H. (2015). Using the think-pairshare strategy to improve students' speaking ability at STAIN Ternate. Journal of Education and Practice, 6(10), 37-45.

Wenger, E., McDermott, R. A., \& Snyder, W. (2002). Cultivating communities of practice: A guide to managing knowledge. Harvard Business Press. 